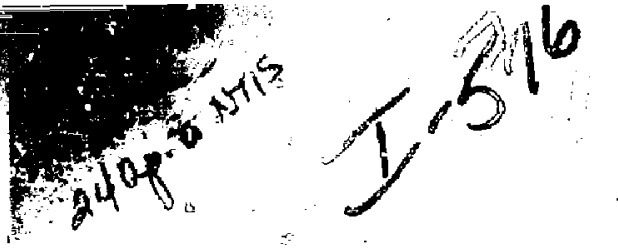

\title{
TNCREAS ING THE LIFE OF CUTTING FLUIDS USED IN THE LLNL MACHINE SHOP
}
C. A. Cadena
R. A. da Roza
J. S. Johnson
R. D. Szidon

Hoveraber 18, 1981

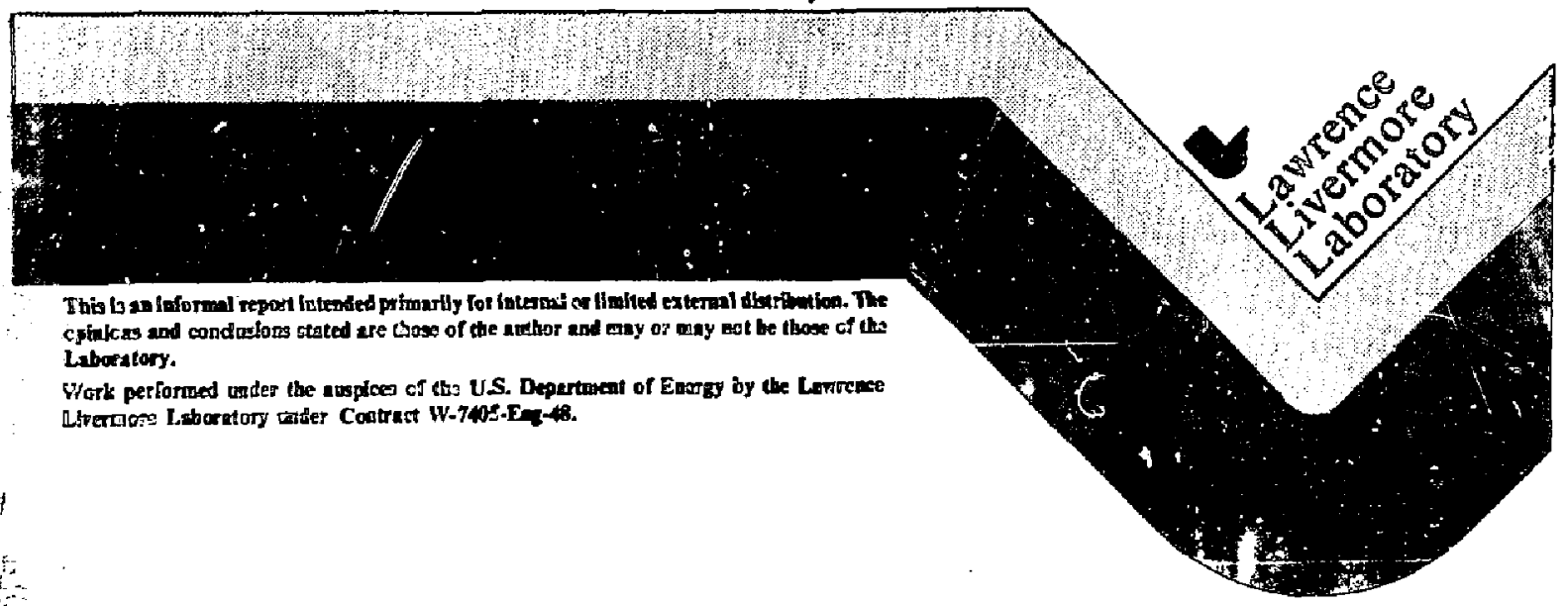

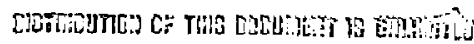




\section{INOREASTMG THE LIFE CP COTTIMG PLOIDS}

USED IN THE LLAL MACBIBE SHOP

\section{INIRODOCITON}

Cutting fluids in Building 321, the main machine shop at tawrence Livermore National Laboratory (LLNL), are being discarded sooner than their manufacturer 3 think is necessary. Since the Numerical Control/Preci: on Machine stop of Building 321 machines uranium and beryllium parts, contaminated liquid wastes are a normal product of its operation. Steps to reduce this volume of contaminated cutting-fluld waste will lower dispo:al costs. In this study we laaked for ways to extend the Lfe af the outting fluids/codlants and therefore reduce the velume of waste produced.

\section{EXPERIMENTAL HETHOD}

First gathered manufacturers' inforation on the five different cutting fluids used in our machine shops and reviewed each fluid's performance. In this examination the folloning items were considered: physical properties, proper mixing directions, and the compatibilities of coolants with the netals we machine. Next, we reviewed information on the equipment that controls and maintains the wer-miscible cutting and grinding fluids (i.e., automatic deionizer, proportioning punp, and oump cleaner).

INCREASING CUTTING-FLUID LIFE

After our preliminary evaluation was completed, we decided to deteraine how the cutting flulds deteriorate with use. As a result of our discussions with the shop superintendent, we decided tc check the characteristics of the various fluids being used in representative machines; we stixded the characteristics of the fluids in nine different machines of Building 321 . The pH, bocteria level, percent coolant concentrate, percent trale oil, and total undisbolved solids were monitored on a week-to-week basis for 6 meeks. During this time, the criteris and procedures used for changing the cutting fludas in the machines were also observed. 
A portable pi meter, Markson Model 92, was used to measure the pH of the cutting fluid. A pE buffer was used to calibrate this instrument before each use. To measure the anount of bacteria in a given sample, an EASICUT,T-TMC bacteria test $k$ it was used. (Practically all serobic bacterla grow on the TTC agar slides.) The slides were simply dipped into the cutting fluid and incubated for 48 hours. The bacterial count per milliliter of the sample was determined by comparing the density of the colonies appearing on the slide with the densities shown on the model chart that came with each $k i t$. The concentration of coolant was determined by American Optical's T/C Refractometer, Model 10440. We converted the number read on the meter to percent coolant concentrate fron a previously determined calibration curve. To measure the percent trang oll, we put samples of the cutting fluid into burets and let them ait for 24 hours; this was a very simple lab procedure to roughly find out how much tramp oil separates from the cutting fluid. To determine if centrifuging or filtering would separate out a significant amount of undissolved solids, the following procedure was performed. Forty-ml samples of cutting fluid were placed in an IEC clinical centrifuge and run at a speed of $7100 \mathrm{rpm}$ (5125 times the force of gravity) for 25 minutes. Filtering was done with a Bichner funnel through a Whatman $\$ 5$ filter paper.

RRMOVING METALS FROM USED CUTTING FLUID:

Reducing the cost of disposing of contaninated spent cutting fluid was a separate aspect of this project. The fluid could be disposed of less expensively--as industrial waste--if the uraniun and beryllium could be filtered or centrifuged out. We tried to determine if uranium and beryllium are soluble in the cutting fluids over time; $s i x$ aifferent samples were prepared or collected for analysis. The first sample was of a fresh Trimsol dilution with D-38 filings; the second was a fresh Trimsol dilution with berylliur filings. Both samples were stirred for 8 hours and aeratad for 4 hours to give the filings a chance to dissolve to the solution. The third and fourth samples, also Trimsol dilutions, were taken from specific wachines in Building 321. The fifth and sixth were cutzol dilutions taken from machines In Building 321. A fraction of each bample was centrifuged and another part filtered in order to determine wich treatment is more effective In eeparating out any solid uranium or beryllium. Centrifuging was dose at 7100 rpm for 25 minuted. Filtering was done through a whatman 5 filter 
paper. All sollds were washed with water and acetone before weighing. Both the I1quid and solid samples were given to the Hazards Control Analytical Laboratory for analysis of uranium, teryll1um, copper, and chromium content.

RESULTS

IMCREAS THG CUTTING-FLUID LIFE

Results from the 6-week study are not complete. It was difficult to determine when the cutting fluid in Building 321 machines was charjged, because changes were unscheduled and unrecorded. A sample of the fresh batch was thus unobtainable, preventing the comparison of the new versus the used fluids. A coolunt concentration of 4-58, as recomnended by the manufacturer, was found in only one of the samples analyzed. The pH in some cases was slightly acidic and should actually have been basic, between 9 and 10. Tramp oil, which stinulates growth of bacteria, was found in each sample. Bacteria tests we_e taken on two separate occasions, and the results ranged from $10^{3}$ to $10^{7}$ aerobic bacteria per nillilfter of sample $\left(10^{4}\right.$ being a slight infection of bacteria ano $10^{6}$ or more, a heary infection). Bacteria feed on the cutting-fluid concentrate, reducing its lubricst, ng value and causing stain, odor, and corrosion. The more important bacteria which are found in water-miscible cutting fluids are Pseudomonas aeruginosa and pseudomonas oleovorans. To keep the bacteria level under control, the more alkaline the solution (the higher the $\mathrm{pH}$ ) the better. However, a fluid of high alkalinity can viry rapidly counteract the normal acid (ph 6.8) condition of the skin and zause dermatitis. We measured the undissolved solfds in the first set of samples, but found the asount to be minimal, so we didn't pursue this step eny further. Por complete data see Table 1.

REPDVTIG METALS FROM USED CUMTING PLUIDS

In deteraining if uranilu and beryllium are soluble in the cutting fluids, we could not conclude frow our anall numer of samples that the fine particles did actusily dissolve. He can say that the raterial contained in our filtered or centrifuged sapples was elther very finely divided part: rulates or in solution. This lindicates that sinple filtration or 
TABLE 1. Comparison of physical properties of cutting fluids from machines in Building 321 over a 6-week period.

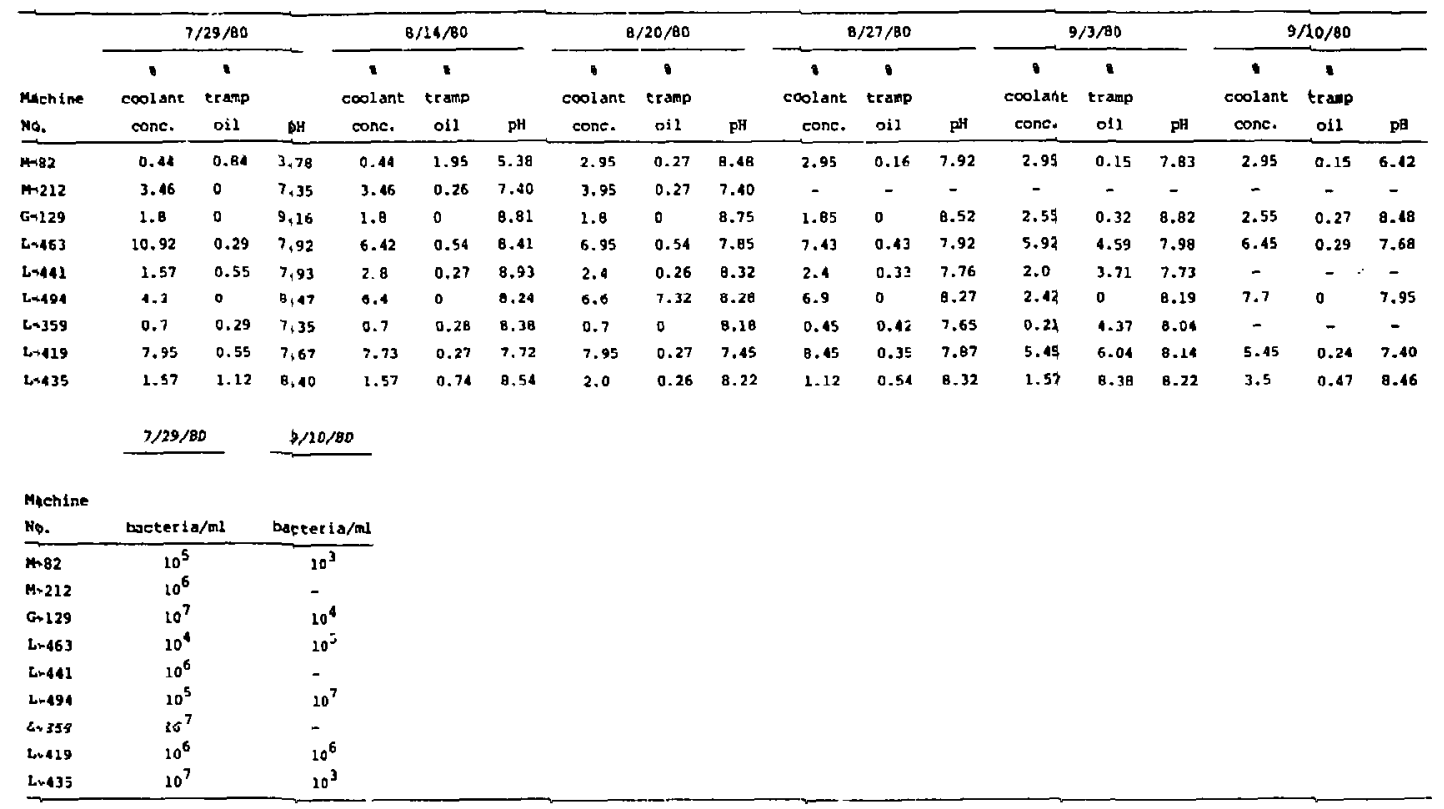


centrifugation will not sufficiently remove the beryllium and D-3B contamination. Inconsistencies in our data point to a problem we were not able to eliminate: that is, representative sampling. Used cutting flulds are emulsions with tramp oil on the top and a viscous sediment on the bottom; it is very difficult to uniformly suspend this material in solu:ton for representative sampling. The volume of our samples was $\mathrm{N}_{25} \mathrm{ml}$, so in a 55-gallon drum this problem will be considerable. For complete data see Table 2.

\section{CONCLUS IONS}

The objective of our study was to extend the useful life of cutting fluids used at LLNL. The following are recommendations which, if implemented and followed in Building 321 or elsewhere, should extend cutting-fluid life significantly.

- To properly use the cutting fluid it should be accurately diluted, preferably with deionized water. Minerals in hard water help the growth of bacteria and use up necessary chemicals in the cutting fluid. The concentration of the cutting fluid should be monitored with a refractometer on a regular basis. Adding a bactericlde to the cutting fluid is recommended by some of the suppliers (Dipeo, Rust Lick, Tapmatic, and Trans United Corporation). The Irans United Corporation rlso suggests adding their Oxcedot Treatment System to prevent the emulsifiers in the cutting fluid from eventually being destroyed with use. Both of these additives are worth using, especially the hactericides, since we found significant concentrations of bacteria in the cutting fluids we analyzed (see Table 1).

- An initial, thorough cleaning of the machine is highly recomended. Any oil leaks in the machine should be ellminated. If tramp oil is a problem, an oil wheel should be installed. A centrifuge can also be used to remove tramp oll for larger quantities, but it is more expensive. Filtering or centrifuging are suggested techniques for renoval of small, solid particles.

- It is recomended that only one brand of cutting fluld be used throughout the shop. This will promote less confusion over which brand is needed for what operation, and there could be one central opot for accurate mixing. It would also be easier for the workers to renember the correct properties of the cutting fluid. 
TABLE 2. Determination of dissolved solids in samples of cutting fluid.

\begin{tabular}{|c|c|c|c|c|c|c|}
\hline $\begin{array}{c}\text { Sample } \\
\text { No. }\end{array}$ & Fraction of sample & $\begin{array}{l}\text { Chromium } \\
\langle(19\}\end{array}$ & $\begin{array}{c}\text { Copper } \\
\text { (ug) }\end{array}$ & $\begin{array}{c}\text { Beryllium } \\
\text { (ug) }\end{array}$ & $\begin{array}{c}\text { Uranium } \\
\left.\text { \{gross beta apm }{ }^{b}\right\}\end{array}$ & $\begin{array}{c}\text { Uranium } \\
\text { (gross alpha apn) }\end{array}$ \\
\hline$A-1$ & $\begin{array}{l}\text { Untreated } \\
\text { Centrifugate } \\
\text { Centrifuged solids } \\
\text { Eiltrate } \\
\text { Filtered solids }\end{array}$ & $\begin{array}{l}- \\
- \\
- \\
-\end{array}$ & $\begin{array}{l}- \\
- \\
- \\
-\end{array}$ & $\vec{u}$ & $\begin{array}{r}2425 \\
2050 \\
60 \\
2425 \\
100\end{array}$ & $\begin{array}{r}2200 \\
1200 \\
25 \\
1350 \\
58\end{array}$ \\
\hline D-1 & $\begin{array}{l}\text { Untrested } \\
\text { Centrifugate } \\
\text { Centrifuged solids } \\
\text { Filtrate } \\
\text { Filtered solids }\end{array}$ & $\begin{array}{l}- \\
- \\
-\end{array}$ & $\begin{array}{l}- \\
- \\
- \\
-\end{array}$ & $\begin{array}{r}27 \\
25 \\
570 \\
29 \\
550\end{array}$ & $\begin{array}{l}- \\
- \\
- \\
-\end{array}$ & $\begin{array}{l}- \\
- \\
- \\
-\end{array}$ \\
\hline$L-264$ & $\begin{array}{l}\text { Untreated } \\
\text { Centrifugate } \\
\text { Centrifuged solids } \\
\text { Filtrate } \\
\text { Filtered solids }\end{array}$ & $\begin{array}{c}62 \\
15.6 \\
0 \\
16.9 \\
2.75\end{array}$ & $\begin{array}{l}528 \\
450 \\
6.25 \\
468 \\
15.0\end{array}$ & $\begin{array}{r}3687 \\
256 \\
1562 \\
296 \\
750\end{array}$ & $\begin{array}{r}1000 \\
600 \\
120 \\
725 \\
90\end{array}$ & $\begin{array}{r}550 \\
300 \\
55 \\
350 \\
48\end{array}$ \\
\hline $5-32$ & $\begin{array}{l}\text { Untreated } \\
\text { Centrifugate } \\
\text { Centritured sollds } \\
\text { Filtrate } \\
\text { Filtered solnc's }\end{array}$ & $\begin{array}{l}53 \\
15.6 \\
1.25 \\
19.4 \\
6.00\end{array}$ & $\begin{array}{l}143 \\
131 \\
1.25 \\
140 \\
12.5\end{array}$ & $\begin{array}{l}375 \\
265 \\
221 \\
281 \\
212\end{array}$ & $\begin{array}{r}4125 \\
3850 \\
625 \\
4125 \\
450\end{array}$ & $\begin{array}{r}2475 \\
2050 \\
3200 \\
2350 \\
220\end{array}$ \\
\hline$L-435$ & $\begin{array}{l}\text { Untreated } \\
\text { Centrifugate } \\
\text { Centrifuged solids } \\
\text { Filirate } \\
\text { Filtered solids }\end{array}$ & $\begin{array}{c}25.0 \\
22.2 \\
0.25 \\
22.2 \\
6.50\end{array}$ & $\begin{array}{l}28.1 \\
65 \\
0.50 \\
68.8 \\
5.00\end{array}$ & $\begin{array}{r}2.13 \\
4.69 \\
0.13 \\
5.62 \\
10.62\end{array}$ & $\begin{array}{l}\operatorname{Los} c \\
\operatorname{LOS} \\
\text { LOS } \\
35 \\
68\end{array}$ & $\begin{array}{r}\text { LOS } \\
\text { LOS } \\
\text { LOS } \\
25 \\
42\end{array}$ \\
\hline$I-359$ & $\begin{array}{l}\text { Untreated } \\
\text { Centrifugate } \\
\text { Centrifuged solids } \\
\text { Filtrate } \\
\text { Eiltered solids }\end{array}$ & $\begin{array}{c}34.3 \\
16.9 \\
0.25 \\
15.9 \\
4.50\end{array}$ & $\begin{array}{l}62 \\
59 \\
1.75 \\
65 \\
5.00\end{array}$ & $\begin{array}{l}3.44 \\
2.34 \\
0.063 \\
2.81 \\
0.63\end{array}$ & $\begin{array}{l}\text { LOS } \\
\text { LOS } \\
\text { LOS } \\
\text { LOS } \\
\text { LOS }\end{array}$ & $\begin{array}{r}\text { LOS } \\
\text { LOS } \\
\text { LOS } \\
5 \\
\text { LOS }\end{array}$ \\
\hline
\end{tabular}

asamples L-264, S-32, L-435, and L-359 are from machines in Building 321 . Samples A-1 and B-1 are unused fluid that had uranium and beryllium purposoly added. Sampling error caused some of the results for the untreated fractions to be less than those for the treated fractions.

boisintegrations per minute.

cuos indicates that the activity level was less than the limit of sensitivity: Los alpha = 4.2 dpm; LoS beta = 10.9 dpm. 
Shop superviaion must make the final decision of what cutting fluld should be used. The choice should be made on the basis of performance, long 1ife, eage of disposal, and customer service.

We have provided a list of reccamendations to the machine shop superiatendent. The recompendations were based on the laboratory analysis of cutting flcids in use, a study of the cutting-flufd nenufacturers' Iiterature, discussions with several manufacturers, and visits to Los Alamos National Laboratory and the Rocky Flats plant. These recomendations, if implemented, should extend the effective life of cutting fluid significantly. We were not able to remove sufficient beryllium or D-36 from used cutting fluids by centrifuging or filtering. The complex nature of this problem will require an extended study by those involved in cutting-fluid disposal. 